\title{
Assessment of the qualitative and quantitative stability of "Wieliczka" Salt Mine (Poland) brines and of their possible use for medicinal purposes
}

\author{
Kajetan d'OBYRN ${ }^{1,2, *}$ and Adam POSTAWA ${ }^{3}$ \\ 1 Cracow University of Technology, Warszawska 24, 31-155 Kraków, Poland \\ 2 "Wieliczka" Salt Mine S.A., Park Kingi 1, 32-020 Wieliczka, Poland \\ 3 AGH University of Science and Technology, Al. A. Mickiewicza 30, 30-059 Kraków, Poland
}

d'Obyrn, K., Postawa, A., 2014. Assessment of the qualitative and quantitative stability of "Wieliczka" Salt Mine (Poland) brines and of their possible use for medicinal purposes. Geological Quarterly, 58 (3): 459-464, doi: 10.7306/gq.1139

\begin{abstract}
Water inflow to a salt mine usually poses a threat to the mine and sometimes even to its existence. On the other hand the healing properties of salt have been known since Antiquity and brines extracted from the mines have been used in the treatment of various diseases. The "Wieliczka" Salt Mine in southern Poland has been conducting organized rehabilitation and therapeutic activities for respiratory tract diseases for almost 200 years. This paper presents preliminary results of a study focused on pre-selection of out-of-deposit water inflows into the mine workings which show the lowest variability in yield and in chemical composition, and which can potentially be used in the health resort operated by the mine. The results indicate that brines from the WVII-16 leak are the only ones which can be taken into account when considering the use of Wieliczka brines for medicinal purposes for baths, rinses, irrigation, and at lower mineralisation levels, in liquid treatments.
\end{abstract}

Key words: "Wieliczka" Salt Mine, brines, balneotheraphy, liquid treatments.

\section{INTRODUCTION}

The healing properties of salt have been known since Antiquity. Prominent humanists and scholars who have visited the Wieliczka mine in southern Poland in the sixteenth century, including Joachim Vadian, Jobst von Willich and Adam Schroeter, relate the use of Wieliczka salt for medicinal purposes. In his record of the visit to the salt mines of Wieliczka and Bochnia, Joachim Vadian wrote: "This salt has particular application in medicine. We even find veins which in their blackness recall extinguished coals. Salt collected from such a vein and ground, in the amount of gold equal to the weight of one denarius, and consumed in a small amount of wine serves - as it was claimed - as a laxative" (Smaroń, 1982).

In the nineteenth century, the physician Feliks Boczkowski initiated medical activities at the mine, consisting of salt baths, in which brine extracted from the mine was used. The treatment traditions of the mine were continued by Professor Mieczysław Skulimowski, who became a mining doctor at the Wieliczka Salt Mine in the 1950s. These traditions are continued today by the "Wieliczka" Salt Mine Health Resort, which treats patients with upper respiratory tract conditions from all over the world. In order to expand the current treatment available, it was decided to construct a graduation tower built in the mine, using water flowing from the deposit into the mine excavations.

\section{* Corresponding author: kajetan.dobyrn@kopalnia.pl}

Received: May 24, 2013; accepted: October 22, 2013; first published online: December, 18, 2013
The brine is water which contains at least $35 \mathrm{~g}$ of dissolved solids per litre (Dowgiałło et al., 2002), usually sodium chloride and often other chemicals such as carbonates and sulphates which endow the brine with unique medicinal properties. These waters are used primarily in the form of baths in liquid treatments, and by inhalation.

The analyses described below, concerning the possibility of using the Wieliczka salt mine brine for medicinal purposes are based on the stability of the inflow of water from outside the deposit with a constant amount of water and its constant chemical and isotopic composition.

The objective of the present study is the pre-selection of the out-of-deposit water inflows into the mine workings which show the lowest variability in yield and in chemical and isotopic composition, and which can potentially be used for medicinal purposes in the health resort operated by the mine.

\section{GEOLOGICAL SETTING AND HYDROGEOLOGICAL CONDITIONS}

The Wieliczka deposit is situated in the western part of the Miocene salt-bearing formation of the Carpathian Foredeep (Garlicki, 1979), and stretches from west to east in a narrow latitudinal strip along the northernmost part of the Carpathians (Fig. 1). The deposit is composed of two parts, a lower layered bed and an upper blocky one (Fig. 2).

The upper blocky part is characterized by a mixture of rocks, with salt lumps (green salt) irregularly arranged within claystone (marly claystone with halite crystals). Among the salt blocks, two main lithological types can be distinguished: laminated 


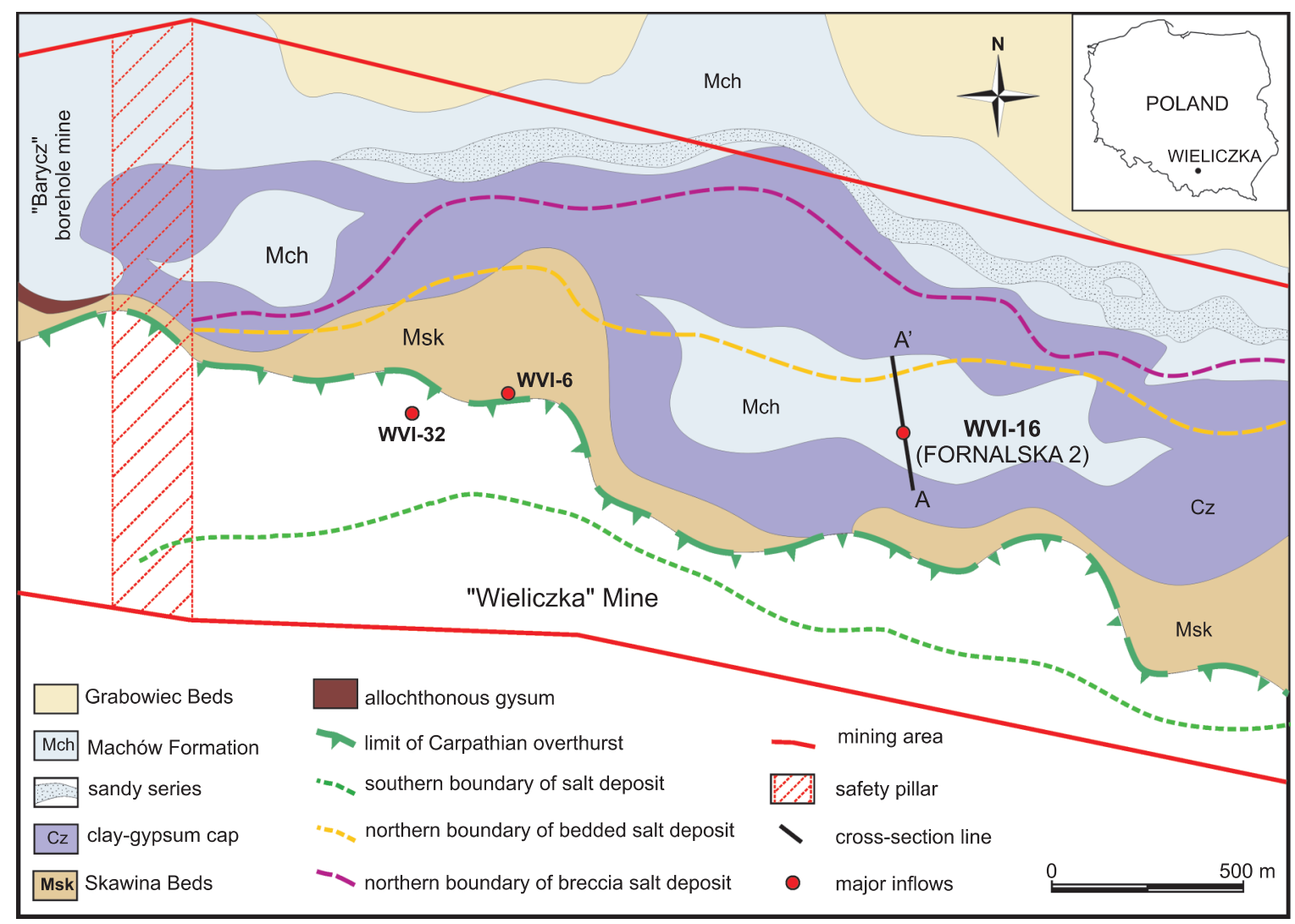

Fig. 1. Geological map of the Wieliczka salt deposit (after Szybist, 2011*)

green salt and rough-crystal green salt together with sporadically occurring dolomitic and lineated salt. In this part of the deposit, also blocks of flysch rocks up to $1 \mathrm{~m}$ across are found (see Kolasa and Ślączka, 1985; d'Obyrn, 2012; Gonera et al., 2012 and references therein).

The lower layered part consists of lithologically varied rock salt layers separated by interlayers of gangue of claystone and siltstone with anhydrite. The salt formations found here include the oldest salts, green layered salts, shaft salt and bronze salts (Gaweł, 1962; Garlicki, 1979).

The bottom of the deposit is formed by the Skawina Formation (Skawina Beds); its southern border is set by the Carpathian flysch, and the northern border, and in part, the cover of the deposit is formed by the Machów Formation (Chodenice Beds) overlain by Quaternary deposits.

The aquifer in the Machów Formation comprises sandy formations represented by fine-grained weakly compacted, clayey and silty sandstones interbedded with clayey rocks. These sandstones show strong tectonic disturbance; and may be rubbly and blocky. Waters found in the sands and sandstones are under a pressure of approximately 1.6 MPa. Hydrogeological tests indicated that their hydraulic conductivities are situated within a very broad range between $5.8 \times 10^{-9} \mathrm{~m} / \mathrm{s}$ and 6.4 $\times 10^{-6} \mathrm{~m} / \mathrm{s}$ (Brudnik et al., 2010). The sandy deposits create, in the Machów Formation, discontinuous aquifer horizons with hydraulic contacts that are difficult to predict. As observations over many years have shown, the greatest water-based threat to the mine is associated with the region of the northern boundary of the deposit, the Machów Formation the aquifer zone at the border of the deposit is especially dangerous (d'Obyrn, 2012). The water threat further increases because of the high concentration of excavation voids in various mining conditions and the related possibility of opening up and expansion of new paths for the inflow of outside-deposit water to the mine as a result of the of the rock mass.

All the previously recorded major water inflows into the mine occurred at the northern boundary of the deposits, with the largest one including:

- a sudden influx of freshwater in 1868 into the Kloski traverse at the rate of approximately $360 \mathrm{~m}^{3} / \mathrm{h}$;

- outflow from the 6-67 opening in the Kosocice longitudinal gallery in 1959, in the amount of approximately $60 \mathrm{~m}^{3} / \mathrm{h}$;

- inflow to the Z-32 leaching plant in 1966, at the rate of approximately $3.6 \mathrm{~m}^{3} / \mathrm{h}$;

- inflow into the Layer 2 Chamber in 1972 in at the rate of approximately $9-20 \mathrm{~m}^{3} / \mathrm{h}$;

- inflow into the Mina transverse gallery in 1992 at the rate of approximately $12 \mathrm{~m}^{3} / \mathrm{h}$ (see: Zuber et al., 2000).

Currently, the largest and most dangerous inflows into the mine are associated with the northern limit of the deposit, from which $85 \%$ of the total water inflow into the mine originates. These leaks include:

- WVII-16 in the Layer 2 Chamber (Fornalska 2) at Level VII;

- WVI-32 under the Z-32 Chamber at Level VI;

- WVI-6 from the Z-28 Chamber at Level VI.

The WVI-32 inflow into the Z-32 Chamber was the result of wet exploitation conducted there in the 1960s. At that point, a sulphate deposit was uncovered in the bottom part of the chamber, which resulted in the waters from that deposit flowing into the chamber, and clearing the hydraulic contacts with the adjacent Machów Formations. The flow does not vary greatly over time, and ranges from $2.16-3.95 \mathrm{~m}^{3} / \mathrm{h}$, but a steady increase in

\footnotetext{
* This reference is lacking in the printed version of the paper; we apologize for this.
} 


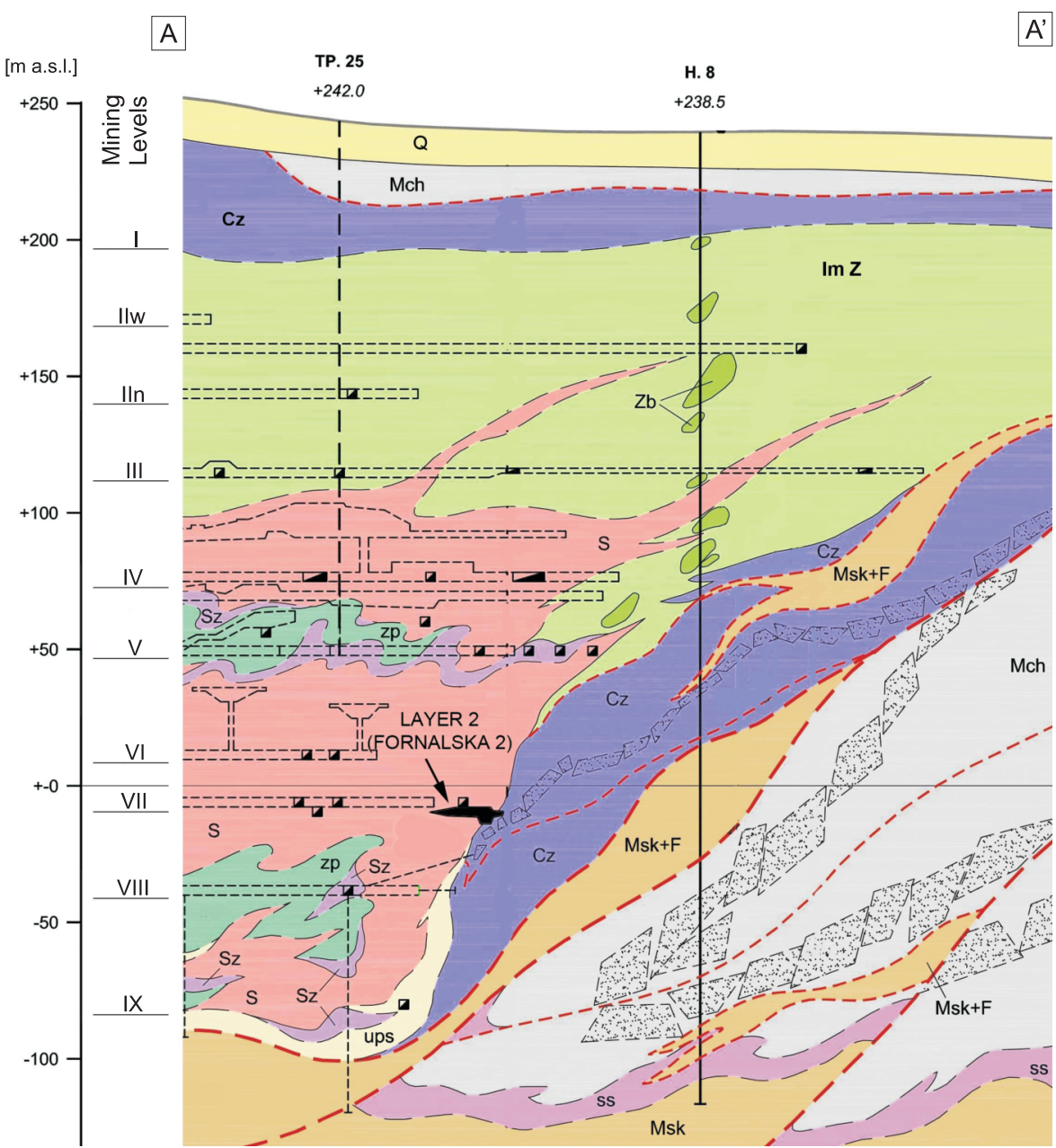

Fig. 2. Geological cross-section NW-SE in the vicinity of the Layer 2 Chamber (after Garlicki et al., 1996 and Szybist, 2011*)
$A^{\prime}$

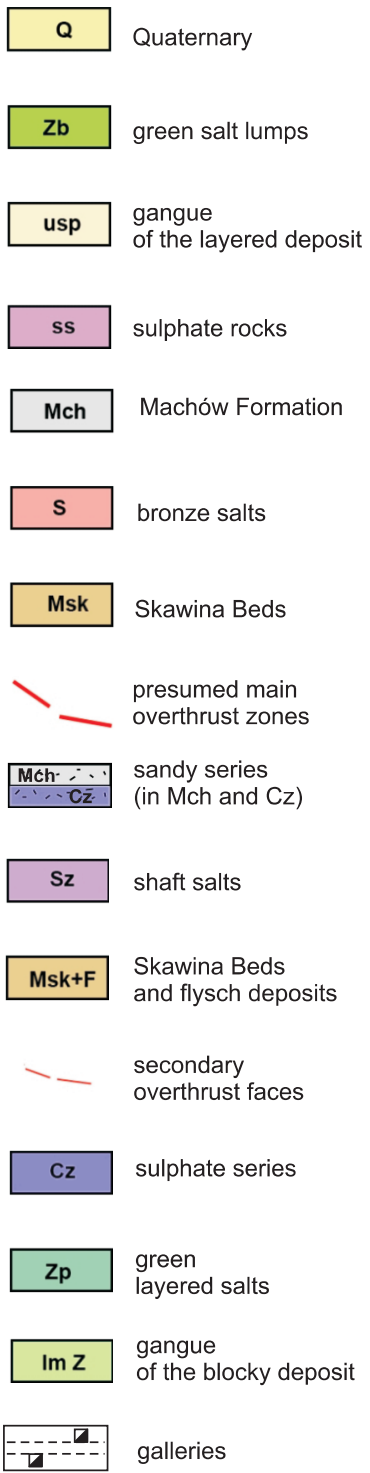

the content of $\mathrm{NaCl}$ in the inflow was observed (from $128 \mathrm{~g} / \mathrm{dm}^{3}$ in 1983 to $253 \mathrm{~g} / \mathrm{dm}^{3}$ in 2012). Also, a systematic study of the isotopic composition of the leak, conducted since 1974, indicates the unstable nature of the flow. Initially, the inflow consisted of old water supplied in the final stage of the last glaciation, then small concentrations of tritium appeared in the inflow, which increased systematically, reaching a value of approximately $30 \mathrm{~T} . \mathrm{U}$. and the isotopic composition showed a trend towards younger water.

The WVI-6 leak from Z-Chamber 28 was also caused by wet exploration conducted there, as result of which adjacent strata in the northern part of the Z-28 Chamber were leached. The flow rate throughout its activity ranged from 0.2 to $1.48 \mathrm{~m}^{3} / \mathrm{h}$, and the isotope analysis carried out indicates glacial water, supplied probably at the end of the last glaciation. Periodically, increased solids content was observed in the inflow, associated with periodic discharge of rock material from the outskirts of the deposit and periodic silting up of the inflow routes, which may result in future changes in the size of the inflow.

Observation over many years and tests conducted on these leaks indicate that only the WVII-16 leak in the Layer 2 Chamber has not displayed changes in the parameters such as yield, $\mathrm{NaCl}$ content, and isotopic composition, which allows it to be selected as the best one for use as a brine in health resort treatment.

\section{GEOLOGICAL STRUCTURE AND HYDROGEOLOGICAL CONDITIONS IN THE LAYER 2 CHAMBER AREA}

The Layer 2 Chamber, which is part of the Layer chambers complex, is located on Level VII of the mine, at a depth of $250 \mathrm{~m}$ (i.e. $11 \mathrm{~m}$ below sea level), in the western part, between the Kinga and Kościuszko shafts. It was exploited between 1940 and 1944 with the use of the dry method as the last of the excavations included in the "Layer" field of exploitation (referred to in the post-World War II period as the "Małgorzata Fornalska" field). After dry exploitation was finished, the chambers were used as brine reservoirs and linked with a below-level gallery to maintain the same level of the brine. In the reservoir, waters flowing into the mine workings from outside the boundaries of the deposit were collected until 1964. The Layer chambers were also periodically used as saturation reservoirs, with incompletely saturated brine, as a result of which the pillars between the chambers were partially leached.

From the Layer chambers, the northernmost bronze salt complex located at Level VII was exploited - the youngest part of the salt succession of the layered deposit.

\footnotetext{
* This reference is lacking in the printed version of the paper; we apologize for this.
} 
The bronze salts exploited in this part of the deposit are characterized by the presence of layers of rock salt separated by an ingrowth of anhydrite marl gangue of variable thickness.

The following main lithological types of bronze salt are observed in the area:

- "eyelet" bronze salt, characterized by the presence in the rock mass of characteristic large crystals of halite "eyelets";

- "streaked" bronze salt, characterized by the presence of a thin claystone laminae in finely crystalline salt;

- "grey" bronze fine-crystal salt, characterized by a high content of terrigenous material (clay, silt and sand);

- "striped" bronze salt, characterized by alternating several-centimetre-thick layers of white and grey salt, contaminated with silt.

The bronze salts in this area are adjacent to sulphate successions which are in contact with the Machów Formation.

The sulphate succession, which in addition contains claystones, siltstones and sandstones, is locally in contact with water-bearing units within the Skawina Beds (borehole $\mathrm{H}-8$ ) and the Machów Formation. Hydrogeological studies conducted at the northern boundary of the deposit, in the vicinity of the Layer 2 Chamber, confirmed the relatively small thickness of the water-bearing formations of the sulphate succession and their very low hydraulic conductivity (between $1.29 \times 10^{-8}$ and $5.88 \times 10^{-9} \mathrm{~m} / \mathrm{sec}$.). The whole succession is more rigid than that containing rock salt, and it has a large number of discontinuous deformations like cracks and dislocations, so it can be assumed that the sulphate series mediates only in the water filtration from the Machów Formation.

The Machów Formation in the Layer 2 Chamber area is formed as sands with clusters of conglomeratic and fine siliciclastic units. These constitute a good water collector since they are strongly folded and cracked. Hydrogeological studies conducted at the northern outskirts of the deposits, long-term observations of leakage from its northern border, and the study of the isotopic composition of water from the leaks lead to the conclusion that many water subsystems exist in the Machów Formation. The hydraulic connections between these systems are complicated, and they have no direct connection to the local Quaternary aquifers.

\section{FEATURES OF THE WVII-16 LEAK IN THE LAYER 2 CHAMBER}

The leak in the Layer 2 Chamber was discovered in December 1972 in the north side wall, in which chamber leaching leading to enlargement of the original size, with extensive exposure of gypsum sandstone of the sulphate was observed. Brine flowed through the gap initially at the rate of $20 \mathrm{~m}^{3} / \mathrm{h}$ with a $\mathrm{NaCl}$ content of $60 \mathrm{~g} / \mathrm{dm}^{3}$. To capture the leakage and secure the chamber, a concrete support dam was constructed along the north side wall, leaving an access gallery to the inflow point, from where it was evacuated and directed into the mine dewatering system. The yield of inflow into the Layer 2 Chamber, which was approximately $20 \mathrm{~m}^{3} / \mathrm{h}$, gradually decreased during 1973-1977 to approximately $10.5 \mathrm{~m}^{3} / \mathrm{h}$. During 1978-1980 it stabilized at a level of approximately $11.5 \mathrm{~m}^{3} / \mathrm{h}$. In 1982, the inflow rate again decreased to approximately $9.5 \mathrm{~m}^{3} / \mathrm{h}$, and then in the years between 1983 and 1991, it ranged from 8.59 to $13.21 \mathrm{~m}^{3} / \mathrm{h}$. Since 1992, the inflow rate has remained below $10 \mathrm{~m}^{3} / \mathrm{h}$ and presently amounts to approximately $9 \mathrm{~m}^{3} / \mathrm{h}$ (Fig. 3).

The content of $\mathrm{NaCl}$ in the brine flowing into the Layer 2 Chamber has not displayed significant changes since the be- ginning of the leak. Occasionally it reached a value below $60 \mathrm{~g} / \mathrm{dm}^{3}$ or above $70 \mathrm{~g} / \mathrm{dm}^{3}$, and has remained within the limits of $60-70 \mathrm{~g} / \mathrm{dm}^{3}$ (Fig. 4).

\section{CHEMICAL COMPOSITION OF BRINE IN THE LAYER 2 CHAMBER}

For the purpose of characterizing the brine chemical composition and as regards the controlling geochemical factors, a detailed chemical analysis (Table 1) of the inflow into Layer 2 Chamber made in 1973 at the laboratory of the Hydrogeological Company in Kraków, was compared with a similar analysis made in 2013 (by the Hydrogeochemical Laboratory of the Faculty of Geology, Geophysics and Environmental Protection, AGH University of Science and Technology in Kraków).

\section{ISOTOPIC TESTS}

Systematic isotopic tests of the WVII-16 leak have been conducted by the Kraków AGH University of Science and Technology, Faculty of Physics and Applied Computer Science

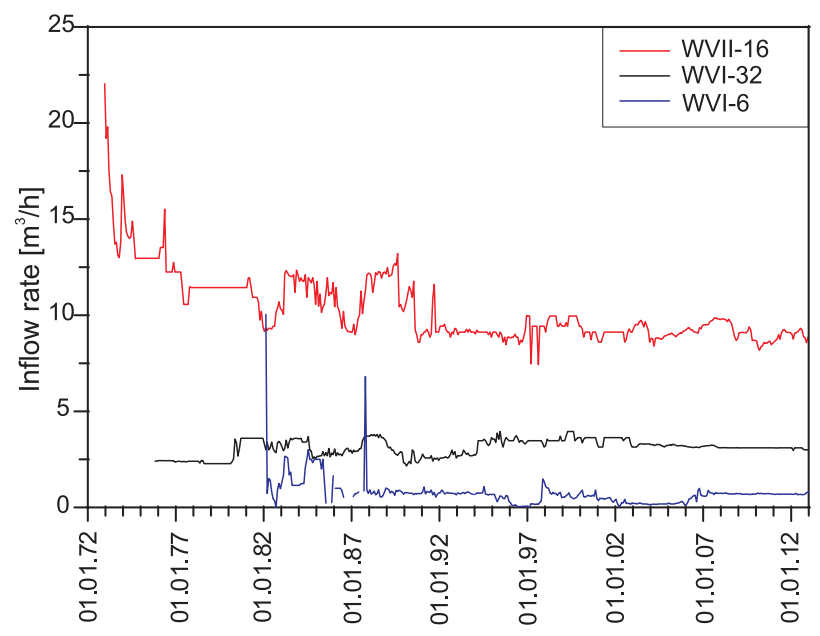

Fig. 3. Inflow rates of selected leaks into the Wieliczka Salt Mine

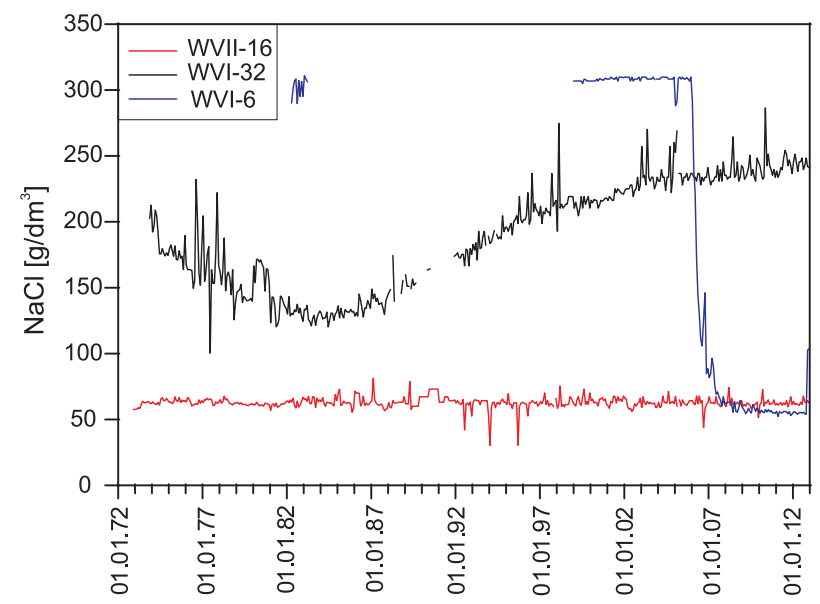

Fig. 4. $\mathrm{NaCl}$ content in brines form selected inflows in the Wieliczka Salt Mine 
Basic physical and chemical parameters of water from inflow WVII-16

\begin{tabular}{|l|c|c|c|}
\hline Parameter & Unit & 07.02 .1973 & 08.01 .2013 \\
\hline TDS & {$\left[\mathrm{g} / \mathrm{dm}^{3}\right]$} & 61.75 & 73.70 \\
\hline $\mathrm{pH}$ & - & 7.00 & 7.10 \\
\hline Chlorides & {$\left[\mathrm{g} / \mathrm{dm}^{3}\right]$} & 34.75 & 35.50 \\
\hline Sulphates & {$\left[\mathrm{g} / \mathrm{dm}^{3}\right]$} & 2.83 & 2.81 \\
\hline Bicarbonates & {$\left[\mathrm{g} / \mathrm{dm}^{3}\right]$} & 0.98 & 1.28 \\
\hline Nitrates & {$\left[\mathrm{mg} / \mathrm{dm}^{3}\right]$} & 6.00 & 0.60 \\
\hline Sodium & {$\left[\mathrm{g} / \mathrm{dm}^{3}\right]$} & 21.68 & 22.71 \\
\hline Potassium & {$\left[\mathrm{mg} / \mathrm{dm}^{3}\right]$} & 24.08 & 46.38 \\
\hline Calcium & {$\left[\mathrm{mg} / \mathrm{dm}^{3}\right]$} & 481.00 & 642.50 \\
\hline Magnesium & {$\left[\mathrm{mg} / \mathrm{dm}^{3}\right]$} & 291.80 & 218.00 \\
\hline Ammonia & {$\left[\mathrm{mg} / \mathrm{dm}^{3}\right]$} & 55.00 & 6.30 \\
\hline
\end{tabular}

Comparison of analyses performed in 1973 and 2013

since 1974, with between one to three measurements between 1974 and 1990, and then once a year. Summarized results of these tests are shown in Table 2.

For the WVII-16 leak in the Layer 2 Chamber, measurements of the radioactive carbon isotope content were also conducted on three occasions (Table 3)

\section{INTERPRETATION}

All the waters flowing into the salt mine workings and contained in the excavations are characteristic $\mathrm{Cl}-\mathrm{Na}$ waters. The content of chloride ions in the anion total in the great majority of leaks amounts to more than $95 \%$, with a similar proportion for the sodium ions in the cation total. This is a natural consequence that inflowing waters are passing through the salt deposit. The water also includes the following ions: sulphate, carbonate, calcium, and magnesium. In the chemical composition of the WVII-16 leak, as recorded in the analyses conducted in 1973 and in 2013 (Table 1) small changes in sulphate and carbonate concentrations were observed, but the composition is stable as far as the chloride and sodium contents are concerned. The stability of $\mathrm{NaCl}$ content in brines from inflow WVII-6 was assessed using a method suggested by Bodiš et al., (2010). The lower limit of the stability range is calculated as 25th percentile minus 1.5 times an interquartile range. The upper limit equals 75 th percentile plus 1.5 times an interquartile range respectively. Figure 5 presents the results of this analysis. As can be seen, the great majority of points representing the $\mathrm{NaCl}$ content falls into the required range.

Undoubtedly, for the brines flowing into the WVII-16 leak to be recognized as treatment waters, other tests and analyses will have to be conducted.

Throughout the observation, the leak displayed a steady isotopic composition. The tritium content measured is within the accuracy of measurement equal to zero, and the values of $\delta^{18} \mathrm{O}$ and $\delta^{2} \mathrm{H}$ are significantly lower than typical values of contempo-

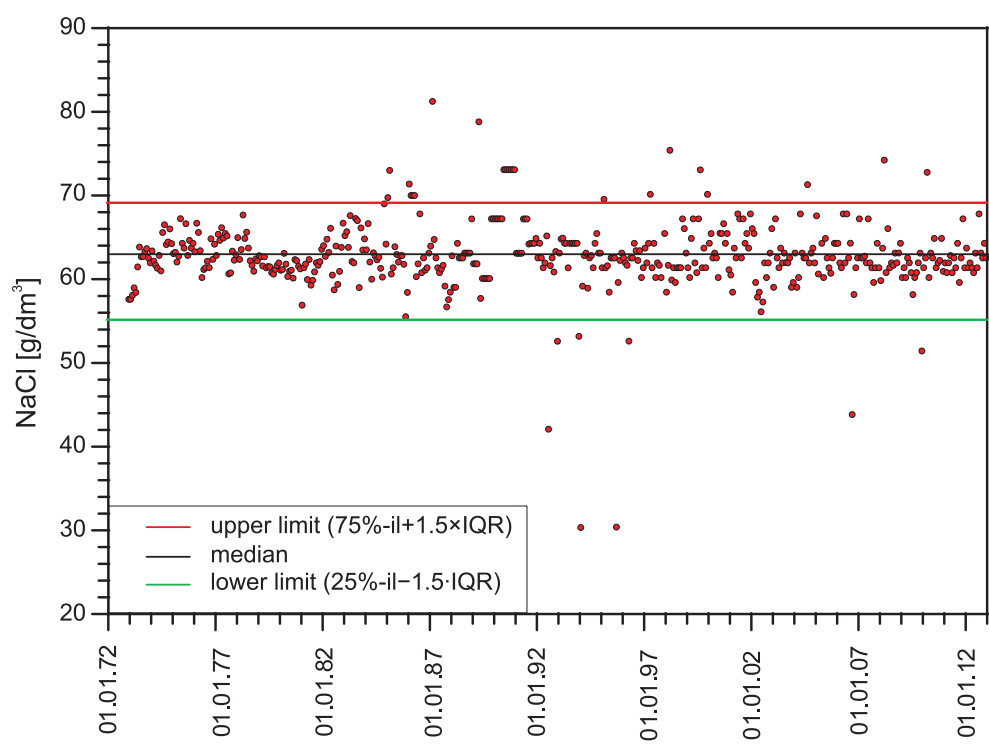

Fig. 5. $\mathrm{NaCl}$ content in brines flowing into the Layer 2 Chamber
Stable isotope composition and the concentration of tritium in the samples collected from the WVII-16 leak in the 1974-2012 period

\begin{tabular}{|l|c|c|c|c|c|}
\hline \multirow{2}{*}{ Parameter } & \multicolumn{2}{c|}{ Range } & \multirow{2}{*}{$\bar{c}$} & \multirow{2}{*}{$\sigma$} \\
\cline { 3 - 5 } & & $\min$. & $\max$. & & \\
\hline$\delta^{18} \mathrm{O}$ & {$[\%$ SMOW] } & -11.10 & -10.20 & -10.71 & 0.18 \\
\hline$\delta^{2} \mathrm{H}$ & {$[\%$ SMOW] } & -78.50 & -72.00 & -75.68 & 1.70 \\
\hline Tritium & T.U. & 0.0 & 5.0 & 0.3 & 0.90 \\
\hline
\end{tabular}

$\overline{\mathrm{x}}-$ arithmetic mean, $\sigma-$ standard deviation

Ta ble 3

Radiocarbon content in the brine from the WVII-16 leak in the Layer 2 Chamber

\begin{tabular}{|l|c|c|}
\hline \multirow{2}{*}{ Year } & $\delta^{13} \mathrm{C}$ & ${ }^{14} \mathrm{C}$ \\
\cline { 2 - 3 } & {$[\%$ PDB] } & Pmc \\
\hline 1977 & -15.2 & $2.6 \pm 1.0$ \\
\hline 1979 & -14.1 & $0.9 \pm 1.0$ \\
\hline 1991 & -14.5 & $1.4 \pm 1.0$ \\
\hline
\end{tabular}

rary infiltration in the area of Kraków. This means that the water which inflows into the Layer 2 Chamber infiltrated in a climate much colder than the current one, probably at the end of the last glacial period, with virtually no tritium content. This interpretation is confirmed by the analyses of ${ }^{14} \mathrm{C}$ in dissolved inorganic carbon compounds.

At the moment when the leak was created in 1972, the water in deposits surrounding this part of the mine was characterized by a negligible flow or no flow whatsoever. After the occurrence of leaks, during the first phase, in which the leak yield reached over $480 \mathrm{~m}^{3} /$ day, it drained the static resources of a small water collector. Probably, further flow was possible thanks to preferential circulation zones in the fissured parts of the Chodenice Beds. The leakage inflow decreased to approx- 
imately $300 \mathrm{~m}^{3} /$ day, and after a few years stabilized at approximately $200 \mathrm{~m}^{3} /$ day. Significant hydrostatic pressure in the first period after the inception of leakage caused the elevation of small amounts of solids (approximately $1.1 \mathrm{~g} / \mathrm{dm}^{3}$ ), which may also have helped to unblock the water circulation routes and facilitate inflow into the mine workings. Isotopic analysis of $\delta^{18} \mathrm{O}$ and $\delta^{2} \mathrm{H}$ indicate glacial water, while the tritium content, initially at approximately $1 \mathrm{~T}$.U., was within the margin of error, and over the last 30 years, was absent. The initial presence of tritium could indicate a component part of modern water, but its content should have increased over time. The results of tritium content measurements, which are well below the margin of error, as well as other data concerning the leak, effectively exclude the participation of modern water components in the formation of the composition of the WVII-16 leak water. Given the confirmed aquifer character of the Chodenice Beds (Brudnik et al., 2010), in which the flow of water through a layer of sandstone only occurs in privileged zones between which there is no or very limited hydraulic contact, it can be assumed by analogy, that in the area of the WVII-16 leak supply a similar hydrogeological condition exists. However, knowledge of the nature of the Chodenice Beds on the outskirts of the Mina traverse on Level IV of the mine, and the long-term chemical and isotopic analyses of waters flowing into the major leaks on levels IV, VI and VII of the mine indicate that only the WVII-16 leak has a stable character. This is most likely due to the large extent of aquifers from which the leak is supplied and the much longer flow path of water. However, despite forty years of observation and tests of the leak, the supply or drain zones of the other layers, from which the water inflows into Level VII in the central part of the mine, cannot be accurately determined. The stability and the size of the inflow may indicate indirect supply from the Bogucice sands, but this hypothesis remains to be tested.

\section{CONCLUSIONS}

The results presented above indicate that waters from the WVII-16 leak are the only ones in terms of volume and relative stability, of the chemical and isotopic composition, which can be taken into account when considering the use of Wieliczka brines for medicinal purposes. This preliminary consideration needs to be further supported by detailed physico-chemical analyses and the assessment of their suitability for specific therapeutic purposes. The next step should consist in channelling the brines in a manner which will be absolutely independent from the mine dewatering system and to ensure that the water intake is tailored to its needs.

The "Wieliczka" Salt Mine has been conducting organized rehabilitation and therapeutic activities of respiratory tract diseases for almost 200 years, and this was reflected in 2011 by the recognition of this activity in the field of underground therapy. Therapeutic activities carried out in parallel with the use of brines have been gradually relegated into the background since the World War II, until they were completely abandoned and saline baths became a thing of the past. It appears important for the development of the mine health resort that this activity is renewed, and medical (balneological) activity is re-established, to use the brine for baths, rinses, irrigation, and at lower levels of mineralisation, in liquid treatments.

Acknowledgements. This work was financially supported by the Polish Ministry of Science and Higher Education and (AGH University, research project no. 11.11.140.026). The authors wish to thank all those involved in the review of this paper.

\section{REFERENCES}

Bodiš, D., Kordik, J., Slaninka, I., Malik, P., Liščak, P., Panak, D. Božikova, J., Marcin, D., 2010. Mineral waters in Slovakia evaluation of chemical composition stability using both historical records and the most recent data. Journal of Geochemical Exploration, 107: 382-390.

Brudnik, K., Czop, M., Motyka, J., d’Obyrn, K., Rogoż, M., Witczak, S., 2010. The complex hydrogeology of the unique Wieliczka Salt Mine. Przegląd Geologiczny, 58: 787-796.

Dowgiałło, J., Kleczkowski, A.S., Macioszczyk, T., Różkowski, A., eds., 2002. Hydrogeologic Dictionary. Państwowy Instytut Geologiczny, Warszawa

Garlicki, A., 1979. Sedimentation of Miocene salts in Poland (in Polish with English summary). Prace Geologiczne, 119.

Garlicki, A., Pulina, M., Różkowski, J., 1996*. Karst phenomena and their influence on the groundwaters threat in the Wieliczka Salt Mine (in Polish with English summary). Przegląd Geologiczny, 44: 1032-1038.

Gaweł, A., 1962. The geological structure of Wieliczka salt bed (in Polish with English summary). Prace Instytutu Geologicznego, 30: 305-327.
Gonera, M., Bukowski, K., d’Obyrn, K., Wiewiórka, J., 2012. Foraminifera in slump deposits of the Badenian (Middle Miocene) Green Stratified Salt in Wieliczka, Poland. Geological Quarterly, 56 (4): 869-880.

Kolasa, K., Ślączka, A., 1985. Sedimentary salt megabreccias exposed in the Wieliczka mine, Fore-Carpathian Depression. Acta Geologica Polonica, 35: 221-230.

d'Obyrn, K., 2012. The analysis of destructive water infiltration into the Wieliczka Salt Mine - a unique UNESCO site. Geological Quarterly, 56 (1): 85-94.

Smaroń, A., 1982. Dwie najstarsze relacje łacińskie o żupach krakowskich z XVI wieku (in Polish). Studia i materiały do dziejów żup solnych w Polsce, 11: 117-158.

Szybist, A., 2011*. Aktualizacja obrazu budowy geologicznej i warunków hydrogeologicznych złoża Wieliczka dla potrzeb projektowania otworów piezometrycznych na północnym przedpolu Kopalni. Archiwum Kopalni Soli Wieliczka.

Zuber, A., Grabczak, J., Garlicki, A., 2000. Catastrophic and dangerous inflows to salt mines in Poland as related to the origin of water determined by isotope methods. Environmental Geology, 39: 299-311.

\footnotetext{
* This reference is lacking in the printed version of the paper; we apologize for this.
} 